\title{
Gondolatok a munkajog dogmatikai fejlődéséről, különös tekintettel a munkáltatói koncepció alakulására
}

\section{Thoughts on the Dogmatic Development of Labour Law, Especially the Development of the Concept of the Employer}

\section{ÖsSZEFFGLALÁS}

A munkajog dogmatikai fejlődési ívének és a munkajog önálló jogággá válását eredményező folyamat feltérképezésének kiemelt jelentősége van a napjainkban hatályos munkajogi szabályozás, ezen belül is a munkáltatói koncepcióra vonatkozó szabályok legteljesebb megismerése érdekében. Azonban, az önálló jogággá válás folyamatának tekintetében jelen tanulmány keretében vizsgálódásom tárgyáva tettem a munkavégzés ókori hagyományinak tanulmányozását, illetőleg azon folyamat feltérképezését, hogy a XVIII-XIX. században lezajló gazdasági, társadalmi közeg változásai milyen befolyással bírtak a hatályos munkajogi szabályozás kialakulásában. A fejlődési folyamat során kulcsfontosságú szempont lett bizonyos védőintézkedések átültetése a munkajog szabályozási rendszerébe, amelyek ezt megelőzően más kötelmek esetében nem kerültek alkalmazásra, továbbá kiemelten jelentős tényezőként jelent meg a magánautonómia biztosítása kollektív viszonylatban is.

Kulcsszavak: felelősségteljes innováció, versenyképesség, regionális versenyképesség

Dr. Berényi Laura, PhD hallgató, Miskolci Egyetem (jogberi@uni-miskolc.hu). 


\section{SUMmaRY}

The mapping of the dogmatic development curve of labour law and the process as a result of which it became an independent branch of law is of paramount importance in order to have a complete understanding of labour law regulations in force today, including the rules on the concept of the employer. However, with regard to the process of becoming an independent branch of law, within the framework of this study I have examined the ancient traditions of work and explored the process of how changes in the economic and social environment in the 18th and 19th centuries affected labour law regulation. During the development process, the transposition of certain safeguards into the regulatory system of labour law, not applied to other obligations previously, have become a key aspect; furthermore, the observance of private autonomy also in collective relationships have appeared as a significant factor.

Keywords: employer, dependent work, industrial revolution, private autonomy

\section{Bevezetés}

A hatályos munkajogi szabályozás és ezen belül a munkáltató koncepcióját érintő több mint két évszázados szüntelen alakulási folyamat legteljesebb megismerése érdekében elengedhetetlen azon folyamatok, kulcsfontosságú szabályozási mérföldkövek vizsgálata, amelyek mind nagy hatással bírtak a jelenkori szabályozási tendenciák kialakulására. Ebből adódóan nélkülözhetetlen górcső alá venni a múlt és elődeink munkájának eredményét, amely a munkajog rendszerében a munkáltatói minőség viszonylatában éreztette hatását.

Meggyőződésem szerint annak érdekében, hogy minél teljesebb és valósághűbb képet lehessen felvázolni a kutatásom tárgyát illetően, elengedhetetlen egyfajta rendszerszemlélet $^{1}$ a vizsgálódásom során. A gazdasági és társadalmi környezet folytonos alakulásának következtében a munkajogi szabályozás is szüntelenül formálódik, s igyekszik lépést tartani a gazdasági és társadalmi eseményekkel annak érdekében, hogy a lehető legjobban alkalmazkodjon a változásokhoz. Prugberger megállapítása szerint, a munkajog a polgári államokban egy evolúciós jogfejlődés eredménye $^{2}$ (Prugberger, 2001:73). Ezen kijelentés véleményem szerint helytállóan írja le a modern munkajog kialakulásának több mint két évszázados fejlődési ívét, amely során az egyszerű bérleti szerződésből (locatio conductio) az egyéni és kollektív kapcsolatokat alakító önálló jogággá fejlődött (Kiss, 2005:15). Evolúciója alatt számos tényező együttesen fejtette ki hatását a munkajog alakulását tekintve, ${ }^{3}$ amelynek legmeghatározóbb folyományaként a munkajog klasszikus magánjogtól való elválását lehet megfigyelni, amely anélkül történt meg, hogy teljes mértékben elveszítette volna a klasszikus magánjogi elvek és értékek által hordozott szemléletet (Kiss, 2005:15). A munkajog és magánjog kapcsolatában tehát a kezdeti időkben önazonosságot lehetett felfedezni a szerződéses liberalizmus időszakában, majd egyfajta távolodási tendencia jelent meg az állami beavatkozás idején, mely a szabályozás közjogi elemekkel tarkítását eredményezte. A munkajog egészen az 1970-es évekig fokozatosan távolodott a magánjog elveitől, ám azt követően, napjainkban is egyre erősödő tendenciaként megfigyelhető a munkajogi szabályozás újbóli közeledése a klasszikus magánjog felé. ${ }^{4}$

Mindezek fényében számos megválaszolandó kérdés felvetődhet a vizsgálódás további irányait tekintve, amelyek közül jelen dolgozatomban a következő kérdésköröket igyekszem feltérképezni:

- Milyen ókori hagyományokkal rendelkezik maga a munkavégzés, s az erre vonatkozó szabályozás?

- Miként alakul a függőségi viszony az egyes korszakokban; a gazdasági vagy pedig a személyi jellegű hierarchikus függés a meghatározóbb?

Hogyan hatott a XVIII-XIX. században 


\section{Tudományos mühely}

lezajló gazdasági, társadalmi közeg változása a munkajogi szabályozásra?

- Továbbá, vizsgálódásom tárgyát képezi a megszülető szabályok kötőerejének alakulására vonatkozó kutatás is.

\section{A KEZDET... AVAGY A ,MODERN MUNKAJOG” ALAPPILLÉREI}

A munkatevékenység, vagyis az ember által kifejtett, alapvető emberi tevékenység az emberiség egész történetében kiemelt szerepet játszik, egészen a kezdeti időktől. Így tehát a munka, kizárólag az emberek egymás közötti kapcsolatteremtő magatartásaként kerülhet vizsgálódásom fókuszába (Kiss et al., 2005:15), vagyis többek között a munkafolyamat, mint közgazdasági fogalom elemzése túlterjeszkedik jelen kutatásom keretein.

\section{Úton a munkajog egységes dogmatikai alapjainak meghatározása felé a jogviszony tárgyára tekintettel}

A munkajog, mint diszciplína a szabályozási tárgyát illetően nem más, mint a munkaviszony és az arra vonatkozó szabályok összessége a tradicionális felfogás értelmében. Ezen koncepciótól kissé tágabb értelmezéssel a munkajog egy normatív keretet jelent a munkaerő-piac valamennyi létező és működő intézménye számára, így a gazdálkodó szervezet, a szakszervezet, a munkáltatói érdekképviselet és az állam, mint munkáltató és jogalkotó számára. Továbbá, kétséget kizáróan megállapítható, hogy a munkajog szoros összefonódást mutat a társasági joggal, társadalombiztosítással és a pénzügyi joggal. Az elemzések kiindulópontja a munkaviszony, mint elkülönülő gazdasági és jogi kategória létezése (Jakab, 2018:19). Igazodva a munkajog elméletéhez, amely szerint a munkajogviszonyban - bár mellérendelt felek szerződnek egymással a polgári jogi alapokat tekintve (Kiss et al., 2000:6) - alapvetően alá-fölérendeltségi helyzet alakul ki a szerződő felek között, a munkavállaló egzisztenciális függése a munkajog mindenkori eszmei alapjának tekintendő (Kun, 2016:406). Így ebben az érte- lemben mindez nem más, mint a függő munka joga (Kiss, 2014:42). ${ }^{5}$

Ezen alapvető, a modern munkajog esszenciális velejárójaként számontartott hierarchikus függés történeti kialakulásának feltérképezését kutatásom jelen pontjához érve nélkülözhetetlennek vélem megejteni.

Az egyéni szükségletek kielégítésén túlmenően már a technológiai fejlődés viszonylag alacsony fokán megjelent a kifejezetten más személy számára történő munkavégzés (Kiss, 2005:15). Ennek egyik változataként a más részére egy meghatározott terméket önállóan előállító, szolgáltatást önállóan nyújtó munka jelent meg, mely tevékenység a piaci forgalomban megjelenő áru képében testesíti meg az emberek közötti kapcsolatot. Viszont az egyén saját, illetőleg mások szükségleteinek kielégítését közvetlenül az egyén által kifejtett munka is reprezentálhatja. Mindez nem jelent mást, minthogy az egyik ember a másik számára, a saját munkaerejének felhasználásával munkát végez. Ez olyan jellegű kapcsolatot hoz létre a felek között, melynek következtében az egyik fél úgy képes gondoskodni a saját megélhetéséről, hogy munkaerejét meghatározott ellenérték fejében mások rendelkezésére bocsátja. Az önálló munkavégzéshez képest mindez általánosságban egy olyan erős gazdasági és személyi jellegü függő viszonyt hoz létre a felek között, mely a modern munkajog egyik lényegi alappillérét jelenti.

A munkaszerződés alapján végzett önállótlan, függő munka dogmatikailag a római jogban a bérlet (locatio conductio) intézményéből fejlődött ki az autark gazdaság jogából, az árutermelő, antik piaci viszonyoknak megfelelő jogrend kialakulásával egyidőben. ${ }^{6}$ A bérlet, a modern munkajog közvetlen dogmatikai előképe gyanánt rendkívül tág szabályozási körrel bírt, így számos élethelyzet jogi rendezésében szerepet játszott (Kiss, 2005:46). Ezzek közül kiemelést érdemel a munkabérlet (locatio operarum) intézménye, mely a szabad ember munkaerejének bérbevételét jelentette a munkáltatója által, munkával töltött idejének arányos díjazása (munkabér) fejében. Ezen konstrukció 
keretében többnyire csupán fizikai jellegű munkavégzésre szerződtek a felek. A szellemi munkák körében, a nagyobb társadalmi értékkel számontartott tevékenységek vonatkozásában a mai megbízási jogviszony (vagyis az úgynevezett mandatum) elsődlegessége volt a jellemző. Ez eredetileg ingyenes jogügyletként terjedt el, csupán később jelent meg, hogy adott esetben honorariumot kötöttek ki a felek a feladat teljesítéséért (Kiss, 2005:45-49). Fontosnak vélem továbbá megemlíteni a függőségi viszony egyik speciális formájaként a későbbi korokban elterjedt iusiurandum liberti intézményét, mint a munkavégzés egyik formáját. A római jog valamennyi korszakában jelentős különbség mutatkozott a státus viszonyokat tekintve a szabad születésű polgár és a felszabadított rabszolga (libertinus) között. A felszabadított rabszolga a patrónusával egy sajátos bizalmi, ám mindemellett függőségi viszonyban is állt, mely meghatározott kötelezettségek teljesítésével járt a jövőre nézve mindkettőjük viszonylatában, ezzel egyfajta speciális függő, hierarchián alapuló helyzetet teremtve. Ugyanis a felszabadított rabszolga számos esetben kötelezte magát egy esküvel megerősített ígéret alapján arra, hogy elvégez meghatározott munkálatokat a patrónusa részére (operae artificiales) (Kiss, 2005:49-50).

A munkajog kialakulásának idején a hangsúly egyértelműen a munkát végző személy kiszolgáltatottságát eredményező gazdasági fiuggésre helyeződött, mely nem csupán egy általános jellemzőként, hanem konkrét ismérvként, a szóban forgó felek viszonyában közvetlenül éreztette hatását. Az idő előrehaladtával, azonban a gazdasági jellegü függés egyeduralkodó koncepcióját felváltotta a személyi függóség elmélete a munkajog egységes dogmatikai alapjainak megteremtése érdekében. A Sinzheimer és iskolája által képviselt felfogás lényegi koncepciója úgy szólt, hogy a munkavállalók a teljesítményükhöz a teljes személyiségüket is adják, amelynek következtében sajátos függőségi helyzetbe kerülnek. Mindez pedig a polgári joggal való szembenállás premisszáján alapult (Kiss, 2000:4). Ezen teória hívői egy korábbi elmélethez nyúltak vissza. Úgy vélték, hogy a szolgálati szerződést (Dienstvertrag) az ősi státusjog alapozza meg, s valamennyi ilyen szerződés sajátos személyi- uralmi viszonyt keletkeztet a szolgálatot adó és szolgálatot igénybe vevő - munkáltató és munkavállaló - között (Zöllner-Loritz, et al., 1992:44-46). Ennek következtében sajátos „szinallagma” alakul ki a felek viszonylatában, melynek két fópillére a munkaadó gondoskodási kötelessége, valamint a munkavállaló hűségkötelessége. A munkajogviszony ún. „személyiségi-közösségi” jellegének felerősödése vitathatatlanul pozitív lendületet adott a munkajog dogmatikai fejlődésének a későbbiekben, azonban anakronisztikus vonásaiból adódóan egyúttal negatív hatásait is éreztette. (Kiss, 2000:4). A későbbi kritika találóan mutat rá, hogy „az a tézis, amely szerint a munkajog egységes rendszere csak akkor jöhet létre, ha a munkajog sajátos fundamentumából, a fuiggóségbôl, és nem 'a munkajogtól idegen szabadságposztulátumból' indulunk $k i$ - végzetes tévedés volt". ${ }^{7}$

A feudalizmus évszázadaiban a munkavégzés alapvetően a jobbágyi státusz keretei között volt elképzelhető. Ebben az időszakban a munkát végző személy (jobbágy) a földesúri birtokon teljesített szolgálatot, vagyis azon a földön élt, s abban a házban lakott, amely a földesúr tulajdonát képezte. Mindez olyan speciális függőségi helyzetet teremtett közöttük, mely akár élethosszig is tarthatott. ${ }^{8}$ A jobbágy - a rabszolga jogállásával szemben nem jogtárgy, hanem jogalany, helyzetét élete valamennyi szegmensére kiterjedően a státusza determinálta. Életviszonyait nem saját maga alakította, ebben egyedüli és meghatározó szerepe a földesúrnak volt. Helyzetét a hűbéri gondoskodás és az ennek fejében történő szolgáltatás és engedelmesség határozta meg alapjaiban. A teljesítendő szolgáltatásnak jogalapját egyedül a jobbágy státusz jelentette, vagyis fontos, hogy nem azért kapott a jobbágy földet, mert egy meghatározott szolgáltatást teljesített, hanem azért kellett teljesítenie, mert ez is a jobbágy létet meghatározó állapot része. Az elvégzendő munkát a földesúr határozta meg, s a jobbágy „munkajogviszonyának” időtartama megegyezett jogállapotának, vagyis 
életének tartamával (Kiss, 2005:50).

Mindezek fényében kijelenthető, hogy a jobbágyság sajátos helyzetében bár központi elemet játszott a hierarchia, s a teljes kiszolgáltatottság, ám mégsem tekinthető viszonyuk a munkajogviszony elődjének. A római jogi hagyományok továbbélése szinte Európa minden pontján megfigyelhető volt, ennek köszönhetően a munkabérlet intézménye is sikeresen kiállta az idő próbáját. Azonban a munkabérlet mellett a céhékben dolgozó segédek, legények (Kiss, 2005:52). ${ }^{9}$ valamint a bányamunkások jogviszonyai is befolyásolták a mai munkajogviszonyokra vonatkozó szabályozás alakulását.

Fontos, jogviszonyt keletkeztető tényezőként megjelent ebben a korban maga a szerződés, mely ugyan létrehozta a felek között a jogviszonyt - kötelmi jellegű kapcsolatot teremtve ezzel - ám a jogviszony tartalmának alakítására már nem volt hatással, mivel a patriarchális tekintélytisztelet szinte valamennyi jogviszony tartalmát és létét alapjaiban határozta meg (Kiss, 2005:51).

Általánosan elfogadott a szerzők körében, hogy a mai „modern” munkajog az iparosodás következtében egyfajta válaszreakcióként alakult ki és formálódott, melynek során a szabályozás középpontjába a munkát vállaló fél fokozottabb védelme, a biztonság megteremtése került. Mindezt az a változó társadalmi, gazdasági közeg hívta életre, mely alapjaiban változtatta meg a termelés szerkezetét a XVIII-XIX. században. Ebből adódóan a kialakuló munkajogi szabályozás kulcsfontosságú szerepe a munkafeltételek meghatározásában rejlett, válaszul az akkori munkakörülmények elviselhetetlenségére. Alapvetően tehát a jogszabályi háttér megalkotását egy paradigmaváltás hívta életre (Jakab et al., 2018:22-24).

\section{Az ipari forradalom hatása}

A XIX. század közepére a céhes, illetve a manufaktúrák keretei közötti munkavégzést felváltotta a gyári termelés. A földjétől megfosztott, s hatalmas számban felszabaduló munkaerő gyárakban, üzemekben tudott el- helyezkedni. A mezőgazdaságban egykoron jobbágyként élők bérmunkásokká váltak, illetve mások háztartásában vállaltak különböző szolgálatokat. Ezen korszak a szerződéses szabadság korszakának tekinthető, melyben a munkaszerződés jogintézménye játszott kiemelt szerepet. Hiszen a magánjogi munkabérlet s az ennek alapját és kereteit meghatározó munkaszerződés teljes mértékben alkalmas volt arra, hogy leképezze a gyártulajdonos és a munkavállaló között létesülő, díjazás ellenében munkavégzésre irányuló jogviszonyt. Ebből adódóan a bérmunkások tömege rendszerint ezzel a magánjogi szerződéstípussal kötelezte magát munkavégzésre. Kiemelendőnek vélem, hogy ebben az időben bár még nem beszélhetünk a munkajogról úgy, mint önálló jogágról, a jogviszony alapjait jelentő hierarchikus alá-fölérendeltségi viszony már ekkor éreztette hatását, s mintegy folyamatosan feszegetve a magánjog kereteit előrevetítette a szabályozási tendenciák alakítását.

A munkaerő áruba bocsátására a jogrendszer az ipari forradalom idején mindezek fényében a magánjog, a vagyonjog elveit $s$ megoldásait alkalmazta. A kezdeti időkben a munkaszerződést klasszikus magánjogi szerződésként kezelték, melyből adódóan a tulajdon szabadsága abszolút elsőbbséget élvezett a munkavállalói érdekekhez képest. Azonban, az idő előrehaladtával láthatóvá vált, hogy hosszabb távon nem tartható a munkajog kizárólagosan a magánjog keretei között, hiszen a magánjogi viszonyok alanyai a piacon mellérendelt felek, ezzel ellentétben a munkáltató és a munkavállaló közötti aszimmetria, hierarchikus függés kétséget kizáróan áthatja a jogviszony egészét (Hajdú-Kun, 2011:59). Ebben az időben így még nem beszélhetünk munkajogról, mint önálló jogágról, hiszen akkoriban a magánjog részét képezte.

Kiemelést érdemel véleményem szerint az a gazdasági tény, amely a változások alapvető mozgatóját jelentette; az iparosodás idején a tókésnek munkára, munkaeröre volt szüksége, igy megvásárolta azokat. Ezen a munkaerő-piacon a tőkésnek nem volt szüksége munkaerő-feleslegre, 
s a munkavégzés kockázatait a munkáltató a munkavégzőre telepítette (Bellace, 2018:13). Viszont amennyiben a munkavégzőre olyan jellegü kockázatokat telepítünk, amelyek viselésére nincs felkészülve, s amelyekkel szemben eszköztelen, mindez határozottan a munkajog kizárólagosan magánjogi jellegének kérdésességét veti fel.

\section{A MAGYAR JOGFEJLŐDÉS}

A XIX. század negyvenes éveiben jelentek meg az első munkajogi tárgyú törvények a kereskedőkről, illetőleg a gyárak jogviszonyairól, s ezekben már olvashatók utalások a szabad munkaerő szerződés általi hasznosításáról. A szabadságharc bukását követően a császári és királyi helytartóság ideiglenes utasításai útján történt meg a kereskedelmi és ipari viszonyok rendezése 1851-ben. Kiemelést érdemel az osztrák ipartörvény-tervezet, mely hatását tekintve mérföldkőnek számít a magyar jogfejlődésben, tekintettel arra, habár nem lépett hatályba, a gyakorlatban mégis alkalmazásra került. A magyar gazdaság, s ezen keresztül a jogrendszer egészére kiemelt hatással bírt az 1862. évi osztrák kereskedelmi törvény, valamint az 1872. és az 1884. évi ipartörvények.

\section{Az 1884. évi ipartörvények}

Alapvető mérföldkőnek számít a modern munkajog kialakulásának útját tekintve a második ipartörvény. Kiemelt jelentősége abban rejlik, hogy bár tartalmát tekintve a szerződéses liberalizmus ideológiájának jegyeit foglalta magában, számos olyan rendelkezést tartalmazott, mely a felek közötti status quo megteremtésére irányult (Kiss, et al., 2005:66-67).

A törvény szerint az iparos és a segédje közti viszony szabad egyezkedés tárgya, ám mindemellett fokozatosan nagyobb szerepet kapott a biztosabb, kiszámíthatóbb foglalkoztatás megteremtése. Az 1884. évi XVII. törvénycikk számos garanciális szabályt rögzített a gyári munkások foglalkoztatásával kapcsolatban. Többek között megahatározásra került azon követelmény, amely szerint a mühelyekben munkarendet kell kifüggeszteni. Tartalmát tekintve a munkarendnek rendelkeznie kell ennek körében: a munkaidő tartamáról, a leszámolás idejére, valamint a munkabér kifizetésére vonatkozó feltételekről, a munkát felügyelők jogairól, a munkásokkal való bánásmódról megbetegedésük, balesetük esetén, a felmondásra vonatkozó szabályokról, valamint a kiszabható pénzbirságról a munkarendet áthágó munkásokkal szemben. ${ }^{10}$

Az ipartörvény továbbá szólt a munkások életének és egészségének kiemelt szerepéről, amikor úgy rendelkezik, hogy „minden gyáros köteles gyárában a saját költségén mindazt létesiteni és fenntartani, ami tekintettel az iparüzlet és telep minöségére, a munkások életének és egészségének lehetö biztositására szolgál." "11 A gyári munkások kiszámíthatóbb foglalkoztatási körülményeihez jelentősen hozzájárult továbbá a munkabér fizetésére vonatkozó kritériumok rögzítése, mely szerint a gyáros köteles a munkásai részére a munkabért készpénzben fizetni, s amennyiben a felek eltérően nem állapodtak meg, úgy a kifizetésnek heti rendszerességgel kell történnie. Azonban, a szabályozás fenntartotta annak lehetőségét is, hogy a munkást adott esetben lakással, tűzifával, földhaszonélvezettel, s akár orvossággal is ellássa a munkát adó, az értük járó összeget pedig a munkabérből vonhatta le. ${ }^{12}$

A felek közötti helyzet kiegyenlítése érdekében az ipartörvény létrehozta az ipartestületeket, melyek alapvető célja: ,,az iparosok közt a rendet és az egyetértést fenntartani; az iparhatóságnak az iparosok közt fentartandó rendre irányuló működését támogatni, az iparosok érdekeit előmozdítani, s őket haladásra serkenteni." 13

Mindezek fényében világosan kirajzolódik, hogy az ipartörvény előfutára volt az állami beavatkozásnak, s a hatálya alá tartozó területeken hosszú időre stabilizálta a munkajogi viszonyokat (Kiss, 2005:67).

\section{A világháborúk idôszaka}

A két világháború közötti időszak munkajo- 
gi kodifikációs tendenciáit szemügyre véve a legalapvetőbb állításként a szabályozásbéli széttagoltság, s a tartalmi differenciáltság fogalmazható meg. A magánmunkajogra vonatkozó egységes szemlélet kialakulásának és szabályozásának hiánya összefüggésben állt a magánjog kodifikációjának elmaradásával. Az 1900-as és 1908-as magánjogi törvénytervezetek azonban a gyakorlatban érvényesültek, mégis a következő fontos állomást a szabályozást tekintve az 1937. évi törvénycikk jelentette, amely egységesen, valamennyi magánszolgálati viszonyra kiterjedt, így egyfajta kerettörvényként került alkalmazásra (Kiss et al., 2005:67-68).

A munkavégzésre irányuló szabályok alapvetően diszpozitív jellegűek voltak 1945 előtt, hiszen a munkajogot ebben az időben még a magánjog részének tekintették. Ezt követően az 1948-as évtől kezdve azonban egyre inkább a kógencia irányába mozdult a szabályozás, összhangban a szocialista ideológia centralizmusával, s a tervgazdálkodással. Mindeközben az 1945 és 1948 közötti átmenti időszakban ezen két szempont váltakozása, kölcsönhatása a meghatározó, valamint, megjelent a modern, hatályos magyar munkajog jogforrási rendszerének is az alapját képező elv, a „klaudikáló kógencia”, vagyis a kedvezőbbség elve. A háborút követően megszülető első magánjogi szabályok tehát a kötelező erőtől a munkavállaló javára eltérést engedtek, ám a szocializmus eltérő szemlélete, gazdasági körülményei szükségtelenné tették ezen haladó logika fenntartását. Az 1948-as esztendő tehát meghatározó fordulatot hozott, tekintettel a szovjet típusú szocialista munkajog recepciójára, mely szakítva az addigi magánjogi hagyományokkal, egyértelműen közjogias jellegű - állami beavatkozáson nyugvó - munkajogi szabályozást teremtett (Kun et al., 2004:349-389; Kiss et al., 2005:68-72).

\section{ZÁRÓ GONDOLATOK}

A munkavégzésre vonatkozó munkajogi szabályozás gyökereinek feltérképezéséhez, a mai alapvető szabályozási tendenciák vizsgálatához közel két évszázaddal is érdemesnek bizonyul visszamenni az időben.

Azonban, véleményem szerint a lehető legteljesebb vizsgálódás érdekében nem nélkülözhető a római jogi alapok feltérképezése, mely máig érezteti hatását a magánjogi alapokkal rendelkező mai, modern munkajog esetében egyaránt.

Kutatásom során, mintegy összegzés gyanánt úgy vélem, indokolt és helytálló lehet kijelenteni, hogy a függő munka rendkívül meghatározó fundamentumait egészen a történelem kezdeti szakaszában vizsgálhatjuk. Ezek köréből alapvetően jelen kutatásomban a függőségi viszony alakulásának fókuszából tanulmányoztam a munkajog dogmatikai fejlődését.

Míg a gazdasági, társadalmi fejlődés bizonyos szakaszán a gazdasági jellegü függőség volt domináns, addig más időkben, s más nézetek szerint a személyi jellegű hierarchikus függés volt a meghatározó. Mindez összhangban áll a szüntelenül változó társadalmi és gazdasági környezettel, tekintettel arra, hogy a munkajog is ezen globális gazdasági és társadalmi közeg által meghatározott, jelentősen befolyásolva az adott korszak munkáltatóit megillető jogosultságok, s teljesítendő kötelezettségek körét.

Kulcsfontosságú megállapításként véleményem szerint kiemelendő, hogy a szolgáltatás a munkajogviszony tárgya - szerződésbeli meghatározása egy olyan differentia specifica, mely ténylegesen rámutat a személyi és gazdasági függőség koncepcióján túlmenően a jogviszony alapvető meghatározottságára, s kereteire. Ennek mentén, a munkajog alapvetően ,azon személyek jogának tekintendő”, akik nem állnak az önállóság azon fokán, hogy ne lenne szükséges a munkaerejük hasznosítása más személy érdekében. Mindezekre tekintettel a munkajog dogmatikai fejlődése során két alapvető szempontot kellett figyelembe venni: Egyrészt olyan védőintézkedéseket (Schutzbestimmungen) kellett átültetni a munkajog szabályozási rendszerébe, amelyek nem voltak ismertek más kötelmeknél. Másrészt rendkívül fontos feladat lett az egyre inkább kollektív viszonylatban érvényre jutó magánautonómia fenntartása (Kiss et al., 2000:3-17). 
Az egészséget nem veszélyeztető és biztonságos munkakörülmények kialakítására vonatkozó határozott fellépés a munkavégzők részéről kétségkívül olyan visszafordíthatatlan folyamatot eredményezett, mely fokozatosan elvezetett a munkajog tisztán magánjogi jellégének elhalványulásához, utat engedve az állami beavatkozásnak. Az iparosodás következtében egy olyan kapcsolat alakul ki a munkavállaló és a munkáltató viszonyában, melynek az alapját egyedül a szerződés, azaz a munkaszerződés képezi. A felek a szerződésben szabadon rögzíthetik a foglalkoztatás körülményeit, összhangban a jogszabályi háttérrel. Vagyis eltűnik a jobbágy-földesúr relációjában megmutatkozó kölcsönös kötelezettségvállalás; egy olyan szerződést láthatunk, amely alapján a munkáltató vállalja, hogy a munkáért bért fizet, mely szabályozási mérföldkő jelenti a mai modern munkajog kialakulását, s önálló jogággá válását, melyben a magánjogi szellemiség, s a közjogi elemek összhangjának megteremtése nézetem szerint a jövőre vonatkozóan is kardinális kérdéskört jelent.

Mindezek fényében, álláspontom szerint kiemelendő, hogy a munkajog tárgya - a más részére végzett önállótlan, függő munka - olyan prioritást jelent, mely alapjaiban határozza meg a munkajog rendeltetését, a munkajog dogmatika fejlődését, s a munkáltatói koncepció szüntelen formálódását.

\section{JEGYZETEK}

1 „A rendszer nem más, mint részeknek vagy elemeknek egésszé rendeződése vagy kombinációja - hogy csak az atom - molekula - sejt - szerv - organizmus - ökológiai rendszer egymásra épülésének hierarchiáját hozzuk példaként. A rendszer az elemek folytonos változása - pl. a szervek a sejtek cserélődése, a társadalmak a tagjaik születése és halála - közepette is fenntartja magát. A rendszertörvények a szellemi jelenségekre is alkalmazhatók. A fogaskerekekből bizonyos rendezettség mellett lesz a toronyóra, a betűk bizonyos rendezettség mellett válnak szöveggé, s a jogi normák bizonyos rendezettség mellett állnak össze jogrendszerré. Mint általában az alkotóelemek, a jogi normák összetartozása is kétféle képet mutat- hat: a halmazét és rendszerét. A halmaz az elemek puszta egymás mellettisége, ... A halmazszerű állapotot haladja meg a renddé szervezett rendszer. ..." Szabó Miklós (2006): Jogrendszer. In: Szabó Miklós (szerk.): Bevezetés a jog-és államtudományokba, Bíbor Kiadó, Miskolc.

2 Lásd még: Deakin, Simon (2000): The many Futures of the Employment Contract. ESCR Centre for Business Research, University of Cambridge, Working Paper No. 191. 2.

3 Ebben az evolúciós fejlődésben nemcsak a változó gazdasági környezetnek és a technológiai fejlődésnek van szerepe, hanem az annak hatására megváltozott munkáltatói struktúrának is. Jelen vizsgálódásom kereteit meghaladja a változó munkáltatói struktúra vizsgálata, azonban a jövőbeni kutatásaim tárgyát ez fogja képezni.

4 Kiss György kifejezetten nagy hangsúlyt fektet műveiben a felek konszenzusának jelentőségére a munkaviszony alakításában, mely véleményem szerint a munkajog magánjoghoz történő fokozatos közeledésére világít rá. Lásd erről: Kiss György (2014): Foglalkoztatás gazdasági válság idején - A munkajogban rejlő lehetőségek a munkajogviszony tartalmának alakítására (jogdogmatikai alapok és jogpolitikai indokok.) Állam-és Jogtudomány, 1. 36.; Kiss György (2017): A munkajog szabályozásának dilemmái, Miskolci Jogi Szemle Különszáma, 12. (2) 273-274.

5 „A munkajog léte végeredményben a ,szabad munkaszerződés" (freier Arbeitsvertrag) megszületésének köszönhető, amely a közjogi megközelítés helyett szabad utat engedett a szerződéses szabadság eszméjének, és ezzel a magánjog érvényesülésének. Ezzel együtt azonban a magánjog rendjében megjelent egy olyan imparitás, amely a szerződés, majd a teljesítés folyamatában a jogviszony - ha a fejlődés e korai fázisában ez a különbségtétel megtehető egyáltalán - alakítását az egyik fél hatalmába adta. Ez az egyenlőtlenség, amelyből egyenesen követke-zett az egyes munkavállaló tartós függősége, gyakorlatilag kiszorította a szerződés elvét (Verdrängung der Vertragsorientierung), amely azért is ellentmondásos, mert ebben a relációban a függőség alapja maga a szerződés volt."

6 locatio conducito operarum: a szabad ember munkájának bérbevétele (vagyoni jellegű csereszerződés), locatio conductio operis: múbérlet, locatio conductio rei: dolgobérlet, mandatum: magasabb szellemi munka végzésére. Gyulavári Tamás meghatározása szerint: a munkajog a jogilag szabályozott munka- 
végzések közül a más részére, ellenérték fejében, szerződés alapján, alárendeltségben végzett, önállótlan munkával foglalkozik. Lásd erről: Gyulavári Tamás (2013) (szerk.): Munkajog. Budapest, ELTE Eötvös Kiadó. Lásd még: Prugberger Tamás - Nádas György (2014): Európai és magyar összehasonlító munka-és közszolgálati jog. Wolters Kluwer, Budapest, 27-31., Hajdú József - Kun Attila (2011): Munkajog I., Patrocínium Budapest. 31-40., Prugberger Tamás (2006): Európai és magyar összehasonlító munka-és közszolgálati jog, Budapest, KJK Kerszöv, 33. és azt követő oldalak.

7 Richardi, Reinhard (1988): Der Arbeitsvertrag im Zivilrechtssystem. ZfA, 7. A személyi függőség elméletéhez kapcsolódóan kiemelendő, hogy a munkajogviszonyban megjelenő és felerősödő személyiségi jellegen túlmenően a függőségből adódó védelmi igény ma is tetten érhető a munkajogi szabályozásban. Ezzel szemben, a hivatkozott kritika arra helyezte a hangsúlyt, hogy a munkajog dogmatikai megalapozásánál nem tekinthető elhatárolási jellemzőnek a saját léthez kapcsolódó gondoskodási képtelenség.

${ }^{8}$ Janice R. Bellace ezt a kapcsolatot írja le a ,tied cottage" kifejezéssel, utalva a felek kötöttségére, amelyet a földesúr tulajdonán való letelepedés és gazdálkodás jelentett. Ez volt még jellemző a középkori céhkeretek között működő családi műhely és kereskedés esetében is, ahol a segéd, inas, valamint a mester között hasonló tartós bizalmi kapcsolat állt fenn egészen a manufaktúrák megjelenéséig, a céhrendszer felbomlásáig. A segédek és a tanulók gyakran a mesternél laktak, és a céh ügyelt arra, hogy őket háztartási munkára ne alkalmazzák. Bellace, Janice R. (2018): The Changing Face of Capital: The Withering of the Employment Relationship in the Information Age. In: Hendrickx, Frank. - Stefano, D. Valerio. (eds.): Game Changers in Labour Law. Shaping the Future of Work. Bulletin of Comparative Labour Relations - 100. Kluwer Law International BV, Netherlands, 11-12. Lásd továbbá: Csizmadia Andor Kovács Kálmán - Asztalos László (1991): Magyar állam-és jogtörténet. Budapest, Pécsi Szikra Nyomda, 113-115. és 123.; Wenzel Gusztáv. (1877): Magyarország városai és városjogai a múltban és jelenben. Értekezések a társadalmi tudományok köréből (4. 9). Magyar Tudományos Akadémia, Budapest.; Prugberger Tamás (1978): A gazdasági szervezetek szabályozásának jogrendszertagozódási kérdései, Szövetkezeti Kutatóintézet Közlemények, 133. sz. könyv. SZÖVORG, Budapest.16-18.
9 Létrejöttek idővel az ún.: „legénycéhek” abból adódóan, hogy a céhmesterek számos esetben akadályozták a legények mesterré válását. Arra szövetkeztek, hogy „egyenrangú félként állapítsák meg a szerződési feltételeket a mesterekkel, illetve az alkalmazás tekintetében saját tagjaiknak előjogokat biztosítsanak, a képzésben is közreműködjenek."

10 1884. évi XVII. törvényczikk 113.§ Lásd: Dr. Pap Dávid: Ipartörvény (1909): (1884. évi törvénycikk.). Magyar Törvények Grill-féle kiadása, Grill Károly Könyvkiadó Vállalata, Budapest, 103.

11 1884. évi XVII. törvényczikk $114 . \oint$

12 1884. évi XVII. törvényczikk 118.\$

13 1884. évi XVII. törvényczikk $126 . \S$

\section{FELHASZNÁLT IRODALOM}

Bellace, Janice R. (2018): The Changing Face of Capital: The Withering of the Employment Relationship in the Information Age. In: Hendrickx, Frank. - Stefano, D. Valerio. (eds.): Game Changers in Labour Law. Shaping the Future of Work. Bulletin of Comparative Labour Relations - 100. Kluwer Law International BV, Netherlands.

Csizmadia Andor - Kovács Kálmán - Asztalos László (1991): Magyar állam-és jogtörténet. Pécsi Szikra Nyomda, Budapest.

Deakin, Simon (2000): The many Futures of the Employment Contract. ESCR Centre for Business Research, University of Cambridge, Working Paper No. 191. 2.

Pap Dávid: Ipartörvény (1909): (1884. évi törvénycikk.). Magyar Törvények Grill-féle kiadása, Grill Károly Könyvkiadó Vállalata, Budapest.

Gyulavári Tamás (2013) (szerk.): Munkajog. ELTE Eötvös Kiadó, Budapest.

Hajdú József - Kun Attila (2011): Munkajog I., Patrocínium Budapest.

Jakab Nóra (2018): Európai és magyar munkajogi szabályozás a változó gazdasági viszonyok között, különös tekintettel a magyar munkajogi kodifikációra. Bíbor Kiadó, Miskolc.

Kiss György (2000): Az új Ptk és a munkajogi szabályozás, különös tekintettel az egyéni munkaszerzódésekre. Polgári Jogi Kodifikáció, 1.szám.

Kiss György (2005): Munkajog. Osiris Kiadó, Budapest.

Kun Attila (2004): A magyar munkajog kezdetei és helyzete 1945 és 1949 között. Acta Universitatis Szegediensis: Acta Juridica et Politica: Publicationes Doctorandum Juridicorum 4: 11 pp.

Kun Attila (2016): Az új Munkatörvénykönyve. In: Jakab, András; Gajduschek, György (szerk.) A magyar jog- 
rendszer állapota, MTA Társadalomtudományi Kutatóközpont, Jogtudományi Intézet

Prugberger Tamás (1978): A gazdasági szervezetek szabályozásának jogrendszertagozódási kérdései, Szövetkezeti Kutatóintézet Közlemények, 133. sz. könyv. SZÖVORG, Budapest.

Prugberger Tamás (2001): Az új Ptk. és a munkajogi szabályozás, különös tekintettel az egyéni és a kollektív munkaszerződésre. In: Manfred Ploetz - Tóth Hilda (szerk.): A munkajog és a polgári jog kodifikációs és funkcionális összefüggései. Tanulmánykötet. Novotni Kiadó, Miskolc.

Prugberger Tamás (2006): Európai és magyar összehasonlító munka-és közszolgálati jog. KJK Kerszöv, Budapest.

Prugberger Tamás - Nádas György (2014): Európai és magyar összehasonlító munka-és közszolgálati jog. Wolters Kluwer, Budapest.

Richardi, Reinhard (1988): Der Arbeitsvertrag im Zivilrechtssystem. ZfA, 7 .

Szabó Miklós (2006): Jogrendszer. In: Szabó Miklós (szerk.): Bevezetés a jog-és államtudományokba, Bíbor Kiadó, Miskolc.

Wenzel Gusztáv (1877): Magyarország városai és városjogai a múltban és jelenben. Értekezések a társadalmi tudományok köréből (4. 9). Magyar Tudományos Akadémia, Budapest.

Zöllner, Wolfgang - Loritz, Karl-Georg (1992): Arbeitsrecht. München, C.H. Beck. 